\title{
Promoting Clean Energy Innovation at the State and Local Level
}

\section{David Popp}

\begin{abstract}
Innovation is an important part of energy policy, and encouraging clean energy innovation is often an explicit goal of policy makers. For local governments, promoting clean energy innovation is seen not only as a pathway to a cleaner economy but also as a tool for promoting the local economy. But is such optimism warranted? There is a substantial literature examining the relationships between innovation and environmental policy, but few studies focus explicitly on innovation at the state and local level. In this paper, I provide key lessons from research on clean energy innovation, focusing on lessons relevant for state and local governments. I then summarize the results of a recent working paper by $\mathrm{Fu}$ et al. (2018) that studied wind energy innovation across individual states in the United States. While state-level policies can promote clean energy innovation, it is overall market size that matters most. Thus, innovation need not occur in those states most actively promoting clean energy. I conclude with lessons for state and local governments drawn from both this work and the broader literature on energy innovation.
\end{abstract}

Keywords: green innovation, induced innovation, climate change, renewable energy, research and development, technology policy

JEL codes: 031, 038, Q48, Q55

Meeting today's most ambitious climate policy goals, such as California's target of relying solely on zero-emission energy sources by 2045 or the Green New Deal's goal of achieving 100 percent zero emission power sources in 10 years' time, requires transitioning from an energy system dominated by fossil energy sources to cleaner, carbon-free, technologies. Recent innovations have lowered the costs of electricity from solar photovoltaic (PV) and onshore wind turbines to levels competitive with electricity generated from fossil fuels. However, many technical challenges remain, such as low-cost battery storage that can both facilitate increased use of intermittent energy

Professor, Department of Public Administration and International Affairs, Center for Policy Research, The Maxwell School, Syracuse University, 426 Eggers Hall, Syracuse, NY 13244-1020

Research Associate, National Bureau of Economic Research, Cambridge, MA

e-mail: dcpopp@maxwell.syr.edu

This article is based on my keynote address given to the 2019 NAREA Workshop on Environmental Regulation and Innovation in Local Communities, Portsmouth, NH, June 12, 2019. The author would like to thank Donna Ramirez Harrington (University of Vermont) and Martin Heintzelman (Clarkson University) for edits to the article.

Agricultural and Resource Economics Review 49/2 (August 2020) 360-373

(C) The Author(s) 2020. This is an Open Access article, distributed under the terms of the Creative

Commons Attribution licence (http://creativecommons.org/licenses/by/4.0/), which permits unrestricted re-use, distribution, and reproduction in any medium, provided the original work is properly cited. 
sources and bring down the cost of electric vehicles as well as smart grid technologies to help manage an increasingly complex electricity grid.

Well-designed climate and energy policies facilitate these technological advances. Pressure from environmental regulations encourages innovations to improve environmental performance. A large literature demonstrates the effect that national regulations have on clean energy innovation (see Popp 2019a for a review). However, in the United States, state governments have taken a leading role in promoting clean energy (e.g., Carley 2011). Cap-andtrade policies in California and the Northeast cover a substantial part of the population, and 29 states use renewable portfolio standards to promote clean energy.

As states race to encourage the growth of renewable energy within their borders, they hope that such policies will promote innovative solutions that not only facilitate reductions in greenhouse gas emissions but that also position their state as a leader in the clean energy field. For instance, in his 2019 State of the State Address, New York Governor Andrew Cuomo introduced a series of renewable energy initiatives by stating, "[L]et's take the next step on the Green New Deal which tackles climate change and starts building the green economy for tomorrow. We know it's coming, let the economy be here [emphasis added]." 1 A State of Texas report on the renewable energy industry proudly notes that "Texas ranked No. 4 in the nation in clean energy-related patents" in 2012 and cites awards made through the Texas Emerging Technology Fund as helping "to create long-term economic benefits to the state through investments in early-stage technology companies, regional innovation centers, and academic research recruitment." ${ }^{2}$

Despite the hope that state-level renewable energy policies will promote innovation within state borders and help states become leaders in renewable energy innovation, little is known about the effect of state-level renewable energy policies on innovation. Existing studies focus on national-level policies, providing evidence that national-level renewable energy policies promote innovation (e.g., Johnstone, Hascic, and Popp 2010; Verdolini and Gaelotti 2011; Nesta, Vona, and Nicolli 2014). This paper begins by providing key lessons from this research on policy and energy innovation, with a focus on lessons relevant for state and local governments. I then summarize the results of a recent working paper by Fu et al. (2018) studying wind energy innovation across U.S. states. I conclude with lessons for state and local governments drawn from both this work and the broader literature on energy innovation.

\footnotetext{
1 https://www.governor.ny.gov/news/video-audio-photos-rush-transcript-governor-cuomooutlines-2019-justice-agenda-time-now, accessed January 14, 2020.

2 "The Texas Renewable Energy Industry," http://governor.state.tx.us/files/ecodev/ Renewable_Energy.pdf, accessed May 22, 2014.
} 


\section{Promoting Clean Energy Innovation}

Given the vast theoretical and empirical literature on clean energy innovation, the most salient points from which to draw lessons for innovation at the local level are discussed below. Popp (2019a) and Popp et al. (2020) provide broader reviews on innovation in the energy sector.

Understanding how policy promotes clean energy innovation involves the study of multiple market failures. Two market failures are particularly relevant:

- Environmental Externalities: In the absence of policy intervention, the cost of pollution is not included in the market price of energy, providing little incentive for consumers or firms to reduce energy use or emissions. In this setting, the market for technologies that reduce emissions will be limited, making commercialization of new technologies difficult and reducing the incentives for innovators. Policies that encourage innovation by addressing environmental externalities to increase the market demand for new technologies are known as demand-pull policies.

- Knowledge Spillovers: The public good nature of knowledge creates spillovers that benefit the society at large and not just the innovator. As a result, the social returns to research and development (R\&D) investment are greater than the private returns (Jones and Williams 1998), so that potential innovators do less research than would otherwise be desirable. Underinvestment holds true for all technologies, not just environmental technologies, and will thus be an issue even if environmental policies to address externalities are in place. Science policy to support research performed in both the private and the public sectors helps bridge this gap. Examples include direct government funding of research projects and indirect support such as tax credits for private-sector research and development. Policies that address knowledge spillovers are known as technology-push policies.

In principle, these two market failures could be addressed separately. Knowledge market failures that apply generally to all types of technologies can be addressed by economy-wide policies that encourage knowledge creation more broadly, while environmental externalities can be addressed by environmental policies to "get the prices right," such as a carbon tax or capand-trade program. However, recent evidence suggests that such broad policy strokes are not enough to promote clean energy innovation.

Despite economists' general enthusiasm for these broad incentive-based policies to address externalities, many governments use a variety of other policies in addition to or instead of these market-based approaches to more directly promote adoption of alternative energy and reduction of emissions. These include fuel economy standards for vehicles, renewable energy mandates, and tax incentives for purchasing rooftop solar photovoltaic 
equipment. Whether targeted or broad-based, policies to promote clean energy can be classified as technology-neutral or technology-specific. Broad mandates that allow consumers and firms to choose the most cost-effective means to comply are technology-neutral. Examples include a carbon tax, which targets all emissions equally, as well as more focused policies such as renewable energy mandates that require utilities to generate a specific portion of electricity from renewable energy but do not specifically dictate the types of renewable sources to be used. Technology-specific policies, on the other hand, stipulate the use of specific technologies. Examples include tax credits for electric vehicles or rooftop solar energy. In Germany, for instance, feed-in tariffs for solar energy were set to be more than seven times higher than the feed-in tariffs for wind energy and thus encouraged investment specifically in solar energy (OECD 2013).

\section{Innovation from Broad-Based Policies}

I first present evidence on innovation resulting from market forces such as higher energy prices or from technology-neutral policies. Most technological solutions to reduce climate emissions address the energy sector through one of two mechanisms: providing cleaner energy resources or improving energy efficiency. Understanding what innovation the private sector will do on these technological areas without targeted support is important for understanding when targeted support will be most effective. Three key lessons emerge from the literature.

First, higher energy prices encourage innovation on alternative energy sources and on some energy efficiency technologies. For example, Popp (2002) finds that a 10 percent increase in energy prices leads to a long-run 3.5 percent increase in the number of U.S. patents in alternative energy and energy efficiency technologies, with most of the effect on patenting activity observed 3.71 years, on average, after an energy price change. Verdolini and Galeotti (2011) use a multicountry sample over a 25-year study period and find a similar relationship between energy prices and patents. Aghion et al. (2016) provide differentiated patenting responses for firms in the automotive industry facing higher fuel prices. They find that a 10 percent increase in fuel price is associated with about 10 percent more low-emission energy patents (such as electric and hybrid cars) and 7 percent fewer fossil-fuel patents (those that improve internal combustion engines).

Second, market prices alone do not encourage sufficient energy efficiency innovation. Since energy efficiency both reduces emissions and reduces costs for firms, there are incentives to develop and deploy energy efficient technologies even without climate or other energy policies in place. However, because reduced emissions are an external benefit, environmental market failures mean that individuals will not consider the social benefits of their energy efficiency investments, leading them to underinvest in energy efficient technologies relative to the social optimum. The effect of energy prices on 
energy efficiency innovation is also limited by their saliency. While studies on the auto industry and on renewable energy find higher energy prices spur innovation, energy prices are less effective at driving innovation and technology adoption geared toward enhancing residential energy efficiency. Prices are particularly ineffective for inducing innovation on less-visible and longer-lived technologies such as insulation that are installed by builders and are not easily modified post-construction. Instead, residential energy efficiency innovations are induced by command and control approaches like building code changes (Noailly, 2012).

Third, even the choice of broad-based policies focusing on overall emissions (e.g., a carbon tax) or on technology-neutral goals (e.g., renewable energy mandates) implicitly favors some technologies over others. Technologyneutral policies promote those technologies that are closest to being competitive in the market without policy support (Johnstone et al. 2010). For example, because the cost of wind energy has historically been lower than other renewables, innovation in countries with renewable energy mandates to provide alternative energy focused on wind. In contrast, technologyspecific policies such as feed-in tariffs supported technologies that were less competitive with traditional energy technologies. These include solar and waste-to-energy technologies that required the guaranteed revenue from a feed-in tariff to compete with traditional energy technologies.

Together, these lessons make it challenging for policy makers to encourage long-term innovation in technologies that are not close to being competitive in the market. Technology-neutral policies that let firms choose those technologies closest to being competitive in the market lead to lower compliance costs in the short-term but may not provide enough incentive to develop technologies with longer-term research needs, such as offshore wind energy. Because no one technology will be fully able to meet all energy demands, complementary, technology-specific targeted policies to promote those technologies that are further from being competitive in the market are also needed.

\section{When Should Policy Target Specific Technologies?}

Recent theoretical work suggests other market failures may justify government support for specific technologies-particularly those furthest from market. Such market failures include learning-by-doing, path dependency, and capital market failures (Acemoglu et al. 2016, Fischer, Preonas, and Newell 2017; Lehmann and Söderholm 2018). Both learning-by-doing and path dependency justify technology-specific deployment policies such as feed-in tariffs or tax credits. Learning-by-doing occurs when early producers and users of a technology generate knowledge through the production and use of technology rather than through $\mathrm{R} \& \mathrm{D}$ activity. This learning results in decreasing costs for themselves and other future users/producers (e.g., Lehmann and Söderholm 2018). While such spillover benefits justify 
subsidizing early adopters of clean energy technology, recent evidence indicates that the external benefits are small relative to existing levels of subsidization (e.g., Nemet 2012, Fischer, Preonas, and Newell 2017; Tang, 2018).

Path dependency creates a market failure only if the costs of shifting from one type of technology to profitable opportunities in another act as a hurdle, preventing adoption of an otherwise more profitable technology (Lehmann and Söderholm 2018). Empirical evidence on path dependency is slim. There is some evidence that path dependency matters in the context of energy innovation (e.g., Aghion et al. 2016; Stucki and Woerter 2017), but none of these studies test whether the observed path dependency results from high switching costs or is simply a response to better research opportunities.

In contrast, there is evidence both suggestive of market failures resulting from imperfect capital markets and that government investments can help. Howell (2017) shows that early financing from the U.S. Department of Energy Small Business Innovation Research (SBIR) program helps clean energy firms overcome capital market failures. However, this same intervention did not influence traditional energy industries such as fossil fuels and biofuels. Likewise, some evidence suggests that clean energy innovations take longer to reach commercialization than other high-technology fields (Popp, 2017; Branstattter and Ogura 2005; Finardi 2011), providing another potential barrier to raising private sector financial support.

Finally, the government can help remove obstacles to commercialization through direct funding and/or performance of research and development (Mowrey, Nelson, and Martin 2010; Weyant 2011). The disproportionately large capital expenses required for significant energy innovations leave a role for collaboration between the public and private sectors to support both initial project development and demonstration projects. Such demonstration projects can promote further learning (Mowrey, Nelson, and Martin 2010). Palage, Lundmark, and Söderholm (2019) find supporting evidence, showing that advanced biofuel patenting increases after investments in demonstration projects in EU countries. While more research is needed, the evidence to date suggests a need for polices that help bridge the gap between laboratory research and commercial success.

\section{The Effectiveness of Government R\&D}

Most policies addressing learning-by-doing, path dependency, and capital market failures focus on commercialization and deployment rather than the supply of innovation itself. High social returns to R\&D justify government research investment to increase the supply of innovation in all industries. Thus, it is important to understand whether the identified spillovers from clean innovation are larger than in other industries. If so, a larger role for government R\&D in clean energy is justified. Several recent papers use patent citation data as evidence of spillovers in clean energy industries, as patent citations are an indicator of how successful an innovation is in 
spurring additional innovations. These studies generally provide support for a larger role for government-funded clean energy R\&D, particularly for technologies that are still emerging. Both Dechezleprêtre, Martin, and Mohnen (2017) and Popp and Newell (2012) find that clean energy R\&D generates large spillovers, comparable to spillovers in other emerging fields such as IT or nanotechnology. Noailly and Shestalova (2017) find similar results, but only for younger clean energy technologies. For emerging technologies such as energy storage, spillover occurs across technology domains, making it less likely private sector inventors can capture the full benefits of these innovations.

Popp (2016) studies the effectiveness of government-sponsored energy research by linking data on scientific publications to public energy R\&D funding and finds the following four key results. First, while $\$ 1$ million in additional government R\&D funding leads to 1-2 additional publications, the lag between initial funding and publication can be as long as ten years. Second, adjustment costs associated with large increases in research funding are of little concern at current levels of public energy R\&D support. These first two results together suggest that while there is room to expand public R\&D budgets for renewable energy, the impacts of any expansion may be delayed for several years. Third, market factors and demand-push policies found to influence private R\&D activity in other papers have little impact on publications, suggesting that current $R \& D$ funding efforts do appear to support different types of research than generated by the private sector. Finally, as the ultimate goal of government energy R\&D funding is not an article but a new technology, Popp (2016) uses citations from patents to scientific literature to link these articles to new energy patents. Lags in both the creation of a new publication and the transfer of this knowledge to applied work mean that public R\&D spending may take over a decade to go from a new article to a new patent.

In general, as evidenced by the discussion above, government R\&D should focus on technologies furthest from the market. Costantini, Crespi, and Curci (2015) compare patenting in conventional first-generation biofuels to patenting in more advanced second-generation biofuels. While technologypush policies do not induce innovation for more mature technologies (e.g., first-generation biofuels), they are important for fostering development in emerging, more advanced technologies. Thus, government support for clean energy R\&D should focus on emerging technological areas such as energy storage rather than more established technologies such as on-shore wind energy.

\section{State and Local Green Energy Innovation}

Each of the papers cited above focuses on national-level policies. While little published evidence exists on the effect of state-level policies on clean energy innovation, studies that consider both foreign and domestic policies provide 
relevant insights. Using data from 1991-2008, Dechezleprêtre and Glachant (2014) compare wind energy patents across OECD countries and find that renewable technology innovation increases with both domestic and foreign demand-pull renewable policies. Further, because foreign markets are larger, the overall impact of foreign policies on innovation are twice as large, on average, as that of domestic policies even though the marginal effect of domestic policies is 12 times higher.

Policy types also matter. Peters et al. (2012) uses patent data from 15 OECD countries spanning 1978 to 2005 to show that both domestic and foreign demand-pull policies (such as renewable portfolio standards or feed-in tariffs) are important for the development of solar PV technology, but technologypush policies such as R\&D subsidies increase only domestic innovation. Focusing on innovation related to energy storage, Fabrizio, Poczter, and Zelner (2017) compare the effect of policy on domestic and foreign innovation. Demand-pull polices promote domestic innovation and increase technology transfer from another country (measured by domestic patent applications filed for technologies that originally filed for patent protection elsewhere), suggesting that increased innovation from environmental policy may also come from abroad. In contrast, technology-push policies promote domestic innovation but do not increase technology transfer.

How might these results translate to state and local efforts to promote clean energy innovation? For instance, while Dechezleprêtre and Glachant (2014) find that trade barriers diminish the influence of foreign environmental policy on local innovation, barriers to marketing renewable energy technologies across states are lower than the barriers for marketing technologies across countries (Coşar, Grieco, and Tintelnot 2015). A recent working paper by $\mathrm{Fu}, \mathrm{Li}$, Ondrich, and Popp (2018) compares wind innovation across U.S. states. This study uses wind patent data for the 48 contiguous U.S. states from 1983 to 2009. They construct policy variables from the Database of State Incentives for Renewables and Efficiency (DSIRE), including measures for several policy types as well as renewable portfolio standards (RPS) and tax incentives. They consider both the effect of in-state policies and a spatially weighted average of policies in other states that accounts for both distance and population to control for potential market size.

Their key result is that overall demand for wind within the United States, rather than in one particular state, drives innovation. As more states adopt renewable portfolio standards, wind innovation increases throughout the country. The effects are substantial. For example, the increase in patents resulting from the policies enacted by seven states in 2007 account for 17 percent of all patents in 2008. Emphasizing the role of overall market size, one of the states with the most wind patent activity, South Carolina, generates little energy from wind and has no renewable energy mandate. Thus, while additional state renewable energy policies are likely to encourage more innovation, politicians should be aware that such innovation may not occur in their own states. Enacting policies to promote renewable energy 
may increase deployment of renewable energy in the state, but will not necessarily make the state a leader in the development of renewable energy technology. As the example of South Carolina suggests, factors such as lower taxes or affordable labor may be a more important determinant for where innovation takes place. Further research is needed to determine the role of energy policy vis-à-vis other industrial policies designed to increase statelevel employment on state-level energy innovation.

\section{Recommendations for State and Local Governments ${ }^{3}$}

Moving forward, the changing nature of energy technology suggests greater challenges lie ahead. Continued growth of intermittent renewable energy sources and their integrations in the grid system requires long-term energy storage solutions and smart grid technologies (IRENA 2017). Energy storage breakthroughs can lead to better batteries for electric vehicles, making them more attractive to consumers by reducing their costs and increasing their range. Because advances in energy storage could have spillover effects to multiple sectors, public sector R\&D will play a more important role in coming years. In addition, significant infrastructure investments will be needed by both public and private sectors to accommodate new technologies such as investing in a network of charging stations for electric vehicles.

The literature on clean energy innovation suggests several guidelines for policy makers interested in furthering clean energy innovation (Popp 2019b). Any policy efforts must begin by creating market demand through policies that address environmental externalities, such as through carbon pricing or cap-and-trade. However, carbon pricing by itself is not enough to bring about breakthrough innovations needed for long-term emission reduction goals. While broad-based policies lower short-run compliance costs, targeted support policies addressing the market failures noted in the earlier section "When Should Policy Target Specific Technologies?" are also needed. Many remaining challenges involve technologies such as energy storage or improved electricity grid management that are difficult for the private sector to develop on its own and that will thus benefit from government R\&D investments.

While these lessons apply for all levels of government, the current political climate in the United States suggests that climate policy progress will come at the state and local level rather than from the federal government. While state efforts on clean energy traditionally have focused on deployment and diffusion, rather than innovation, what additional considerations should state and local governments consider to enhance investment in clean energy research and development?

3 Several of the recommendations in this section are drawn from Popp (2019b). 


\section{Coordinate targeted policy efforts}

For state governments, many of the benefits from technology policy will spill over to other states. For instance, some states require that a minimum share of renewable energy come from solar technology (e.g., a carve-out for solar). These requirements promote the development of solar energy but also increase the short-run costs of generating electricity. Similar to the public goods problem for knowledge discussed earlier, the resulting technology improvements benefit consumers everywhere, not just consumers in the local community. For example, feed-in tariffs for solar energy raised electricity prices in Germany. Innovation induced by these feed-in tariffs increase the external benefits of those subsidies by 22 percent. However, most of those benefits are generated by future solar panel adoption that occurs outside Germany due to the lower solar panel prices that result (Gerarden 2018). For smaller local governments, appropriating the external benefits from innovation will be even more difficult. Thus, while first-order benefits such as reduced emissions may be enough to justify the use of clean energy policies at the state and local levels, the second-order benefits of induced technological change should be of less concern to local policy makers in all but the largest states. As the work by Fu, Li, Ondrich, and Popp (2018) demonstrates, there is no guarantee that clean energy innovations will occur in the communities most strongly promoting clean energy.

One way to overcome this appropriation problem is for states to coordinate renewable energy policies. The Regional Greenhouse Gas Initiative limiting emissions from the electricity sector among ten northeastern states is an example of such coordination. Since overall market size is more important than local environmental regulations for spurring clean energy innovation, coordinated policies can better create the market scale necessary for inducing private sector innovation. An example where policy coordination may be particularly helpful is in building codes. As noted in Noailly (2012), changes to building codes in Europe increased energy efficiency innovation. Because building codes are set at the state and local level in the United States, coordination among local governments is more likely to create the market scope necessary to spur innovation in response to building code changes.

\section{Coordinate research and development}

Improving coordination among jurisdictions is particularly important for direct $\mathrm{R} \& \mathrm{D}$ funding. The federal government is in a better position to fund energy research and development spending, both because it is better able to diversify risk and because federal research spending avoids potential duplication of research programs across multiple states. Nonetheless, states do fund some energy R\&D. In 2017, U.S. state governments spent $\$ 307$ million on energy R\&D. Although that is just a fraction of the $\$ 9.2$ billion spent by the DOE, almost 80 percent of this funding came from just two 
states: California ( $\$ 185.6$ million) and New York ( $\$ 55.9$ million). Thus, there is room for other states to expand energy R\&D budgets. However, enhancing state energy R\&D investments faces two particular challenges.

First, despite the earlier evidence on the importance of government funding for early-stage research, much of the R\&D support from states focuses on deployment rather than on early-stage research. The California Energy Commission (2015) explicitly states, "Energy Commission RD\&D [research, design, and development] programs bridge the gap between the laboratory and the market." California provides initial funding for green energy entrepreneurs through California Sustainable Energy Entrepreneur Development Initiative (CalSEED) awards. Similarly, the NY Green Bank, founded in 2014, leverages private sector financing to increase clean energy investments. NY Green Bank addresses potential capital market failures by operating in markets with limited competition. Such policies can address capital market failures noted earlier, but they do not substitute for a lack of investment in basic energy research at the federal level.

Second, although both California and New York have taken leading roles in clean energy investment, for smaller states it is difficult to invest in research at levels that would have an impact on technological improvements. For smaller states, coordinating energy R\&D efforts would increase the impact of individual investments. Coordination would also help states avoid potential duplication of research effort. As an example, in 2018 staff from New York and California helped review research proposals on microgrids and energy storage to each other's state R\&D programs to learn about the national state of research on each technology (Orta 2019). Coordination would also help diversify risk by both spreading initial investments across multiple jurisdictions and providing sufficient funding to develop a diverse portfolio of projects.

The EU Strategic Energy Technology Plan (SET-Plan) provides an example of efforts to increase coordination of research efforts across jurisdictions (Dechezleprêtre and Popp 2017). Implementation of the SET-Plan currently includes 17 joint programs in the European Energy Research Alliance; these programs set research priorities for various renewable technologies and encourage coordination among researchers in different countries and different sectors, including industry (European Energy Research Alliance n.d.). Since the inception of the SET-Plan in 2006, EU researchers have become more integrated, as demonstrated by increasing rates of patent citations among EU researchers in different countries (Conti et al. 2018). A consortium of states could similarly pool funds for energy R\&D, both allocating it among researchers in member states and setting aside a share of funding specifically for cross-state collaborations.

\section{Provide a supportive regulatory environment}

State governments can also help foster clean energy innovation by fostering a supportive regulatory environment. Tang (2018) finds that learning-by-doing 
is greatest for wind farms operating on transmission systems operated by independent system operators or regional transmission organizations rather than privately owned and vertically-integrated transmission systems owned by major utilities. Similarly, Nesta, Vona, and Nicolli (2014) show that deregulated or liberalized energy markets in combination with supportive renewable energy policies foster more innovation than when similar policies are implemented in more traditionally regulated energy markets. Likewise, Jamasb and Pollitt (2011) show that patents for non-nuclear electricity and renewable technologies increased in the UK after market liberalization. Thus, increasing competition and flexibility in electricity markets through deregulation may also increase clean energy innovation.

\section{References}

Acemoglu, D., U. Akcigit, D. Hanley, and W. Kerr. 2016. "Transition to Clean Technology." Journal of Political Economy 124(1): 52-104.

Aghion, P., A. Dechezleprêtre, D. Hemous, R. Martin, and J. Van Reenen. 2016. “Carbon Taxes, Path Dependency and Directed Technical Change: Evidence from the Auto Industry." Journal of Political Economy 124: 1-51.

Branstatter, L., and Y. Ogura, 2005. "Is Academic Science Driving a Surge in Industrial Innovation? Evidence from Patent Counts." NBER Working Paper \#11561.

California Energy Commission. 2015. "Investing in Energy Innovation.” California Energy Commission, Sacramento, CA.

Carley, S. 2011. "The Era of State Energy Policy Innovation: A Review of Policy Instruments." Review of Policy Research 28 (3): 265-294.

Conti, C., M.L. Mancusi., F. Sanna-Randaccio, R. Sestini, and E. Verdolini. 2018. "Transition Towards a Green Economy in Europe: Innovation and Knowledge Integration in the Renewable Energy Sector." Research Policy 47: 1996-2009.

Coşar, A.K., P.L.E. Grieco, and F. Tintelnot. 2015. "Borders, Geography, and Oligopoly: Evidence from the Wind Turbine Industry." Review of Economics and Statistics 97(3): 623-637.

Costantini, V., F. Crespi, and Y. Curci. 2015. "A Keyword Selection Method for Mapping Technological Knowledge in Specific Sectors Through Patent Data: the Case of Biofuels Sector." Economics of Innovation and New Technology 24(4): 282-308.

Dechezleprêtre, A., and M. Glachant. 2014. "Does Foreign Environmental Policy Influence Domestic Innovation? Evidence from the Wind Industry." Environmental and Resource Economics 58(3): 391-413.

Dechezleprêtre, A., R. Martin, and M. Mohnen, M. 2017. "Knowledge Spillovers from Clean and Dirty Technologies: A Patent Citation Analysis." Grantham Research Institute on Climate Change and the Environment Working Paper No. 135.

Dechezleprêtre, A., and D. Popp. 2017. Fiscal and Regulatory Instruments for Clean Technology Deployment in the European Union. In Ian Parry, Karen Pittel, and Herman Vollebergh (eds.) Energy Tax and Regulatory Policy in Europe: Reform Priorities. Cambridge, MA: MIT Press, 167-213.

European Energy Research Alliance (EERA). n.d. "About Joint Programmes: What Is an EERA Joint Programme?" Brussels, Belgium: European Energy Research Alliance.

Fabrizio, K.R., S. Poczter, and B.A. Zelner. 2017. "Does Innovation Policy Attract International Competition? Evidence from Energy Storage." Research Policy 46: 1106-1117.

Finardi, U. 2011. "Time Relations between Scientific Production and Patenting of Knowledge: The Case of Nanotechnologies." Scientometrics 89(1): 37-50. 
Fischer C., L. Preonas, and R. Newell. 2017. "Environmental and Technology Policy Options in the Electricity Sector: Are We Deploying Too Many?" Journal of the Association of Environmental and Resource Economists 4(4): 959-984.

Fu, W., C. Li, J. Ondrich, and D. Popp. 2018. "Technological Spillover Effects of State Renewable Energy Policy: Evidence from Patent Counts." NBER Working Paper \#25390.

Gerarden, T. 2018. "Demanding Innovation: The Impact of Consumer Subsidies on Solar Panel Production Costs." Harvard Environmental Economics Program Discussion Paper 18-77.

Howell, S.T. 2017. "Financing Innovation: Evidence from R\&D Grants." American Economic Review 107(4): 1136-1164.

International Renewable Energy Agency. 2017. Accelerating the Energy Transition Through Innovation. Paris, France.

Jamasb, T., and M.G. Pollitt. 2011. "Electricity Sector Liberalisation and Innovation: An Analysis of the UK's Patenting Activities." Research Policy 40: 309-324.

Johnstone, N., I. Hascic, and D. Popp. 2010. "Renewable Energy Policies and Technological Innovation: Evidence Based on Patent Counts." Environmental and Resource Economics 45(1): 133-155.

Jones C., and J. Williams. 1998. "Measuring the Social Return to R\&D." Quarterly Journal of Economics 113: 1119-1135.

Lehmann, P., and P. Söderholm. 2018. "Can Technology-Specific Deployment Policies Be CostEffective? The Case of Renewable Support Schemes." Environmental and Resource Economics 71: 475-505.

Mowrey, D.C., R.R. Nelson, and B.R. Martin. 2010. "Technology Policy and Global Warming: Why New Policy Models are Needed (or Why Putting New Wine in Old Bottles Won't Work)." Research Policy 39: 1011-1023.

Nemet, G.F. 2012. "Knowledge Spillovers from Learning by Doing in Wind Power." Journal of Policy Analysis and Management 31(3): 600-621.

Nesta, L., F. Vona, and F. Nicolli. 2014. "Environmental Policies, Competition, and Innovation in Renewable Energy." Journal of Environmental Economics and Management 67: 396-411.

Noailly, J. 2012. "Improving the Energy Efficiency of Buildings: The Impact of Environmental Policy on Technological Innovation." Energy Economics 34: 795-806.

Noailly, J., and V. Shestalova. 2017. "Knowledge Spillovers from Renewable Energy Technologies: Lessons from Patent Citations." Environmental Innovation and Societal Transitions 22: 1-14.

OECD 2013. Renewable Energy Policy Dataset, version March 2013. Compiled by the Empirical Policy Analysis Unit of the OECD Environment Directorate (Johnstone, N., Haščič, I., Cárdenas Rodríguez M., Duclert, T.) in collaboration with an ad hoc research consortium (Arnaud de la Tour, Gireesh Shrimali, Morgan Hervé-Mignucci, Thilo Grau, Emerson Reiter, Wenjuan Dong, Inês Azevedo, Nathaniel Horner, Joëlle Noailly, Roger Smeets, Kiran Sahdev, Sven Witthöft, Yunyeong Yang, Timon Dubbeling), available at http://www.oecd.org/env/consumption-innovation/finance.htm, last accessed February 26, 2019.

Orta, J. 2019. Electric Program Investment Charge 2018 Annual Report. California Energy Commission. Publication Number: CEC-500-2019-017-CMF.

Palage, K., R. Lundmark, and P. Söderholm. 2019. "The Impact of Pilot and Demonstration Plants on Innovation: The Case of Advanced Biofuel Patenting in the European Union." International Journal of Production Economics 210: 42-55.

Peters, M., M. Schneider, T. Griesshaber, and V.H. Hoffman. 2012. "The Impact of TechnologyPush and Demand-Pull Policies on Technical Change-Does the Locus of Policies Matter?" Research Policy 41 (8):1296-1308.

Popp, D. 2002. "Induced Innovation and Energy Prices." American Economic Review 92(1): 160-180. 
2016. "Economic Analysis of Scientific Publications and Implications for Energy Research and Development." Nature Energy 1(4), 1-8, DOI: 10.1038/nenergy.2016.20.

— 2017. "From Science to Technology: The Value of Knowledge from Different Energy Research Institutions.” Research Policy 46(9): 1580-1594.

— 2019a. "Environmental Policy and Innovation: A Decade of Research." International Review of Environmental and Resource Economics 2019, 13(3-4): 265-337.

—. 2019b. "Promoting Innovation for Low-Carbon Technologies," Policy Proposal 201914, The Hamilton Project, Brookings Institution, Washington, DC.

Popp, D., and R. Newell. 2012. "Where Does Energy R\&D Come From? Examining Crowding Out from Energy R\&D." Energy Economics 34(4): 980-991.

Popp, D, J. Pless, I. Haščič, and N. Johnstone. 2020. "Innovation and Entrepreneurship in the Energy Sector, Forthcoming in The Role of Innovation and Entrepreneurship in Economic Growth, eds. A. Chatterji, J. Lerner, S. Stern, and M.J. Andrews, University of Chicago Press. Stucki, T., and M. Woerter. 2017. "Green Inventions: Is Wait-and-See a Reasonable Option?" The Energy Journal 38(4): 43-71.

Tang, T. 2018. "Explaining Technological Change in the US Wind Industry: Energy Policies, Technological Learning, and Collaboration." Energy Policy 120: 197-212.

Verdolini, E., and M. Galeotti. 2011. "At Home and Abroad: An Empirical Analysis of Innovation and Diffusion in Energy Technologies." Journal of Environmental Economics and Management 61: 119-134.

Weyant, J. 2011. "Accelerating the Development and Diffusion of New Energy Technologies: Beyond the 'Valley of Death."' Energy Economics 33: 674-682. 